\title{
Effect of Transcutaneous Electrical Nerve Stimulation on Menstrual Symptoms Among Adolescent Girls
}

\author{
Soad El-Sayed Mohamed Ibrahim, Nursing Teacher \\ Ministry of Health Hospitals, Alexandria
}

\author{
Sahar Anwar Rizk*, Professor \\ Obstetric and Gynecologic Nursing, Faculty of Nursing, Alexandria University
}

Isis Emile Gohar, Assistant Professor

Obstetric and Gynecologic Nursing, Faculty of Nursing, Alexandria University

*Corresponding author: Sahar Anwar Rizk

E-mail: soanwar@yahoo.com

\begin{abstract}
Menstruation and menstrual symptoms includes affective, social and somatic symptoms that occur around the time of menses. Because of recent concerns about non-steroidal anti-inflammatory drugs (NSAIDs). Today, there is a great tendency to use complementary and alternative medicine (CAM), for the relief of dysmenorrhea such as Transcutaneous Electrical Nerve Stimulation (TENS). Objective: Explore the effect of Transcutaneous Electrical Nerve Stimulation (TENS) on menstrual symptoms among adolescent girls. Setting: The study was conducted at Technical Institute of Nursing named "Dar Ismail" affiliated to the Ministry of Health and Population in Alexandria city. Subjects: The sample comprised 100 eligible female students who were suffering from moderate to severe primary dysmenorrhea. They were assigned equally into 2 groups: study group and control group. Tools: Three tools were validated and used for data collection; Students' Basic Data Structured Interview Schedule, Visual Analogue Pain Intensity Scale, and Menstrual Symptom Questionnaire. Results: The main study findings show that, before intervention there was no statistically significant difference between the study and control groups regarding the severity of primary dysmenorrhea and its associated symptoms. Yet, students who received TENS application showed significantly reduction on the severity of dysmenorrhea pain $(P<0.004 \& p=0.009 \& p=0.047)$ as well as daily life activities than control group, after intervention. On the other hand the severity of nausea /vomiting, dizziness/ tired were significantly improved among study than control group at first and third day of intervention $(P<P<0.043 \& p=0.001) \&(P<0.001, p=0.040) \&(P<0.004 \& p=0.003)$. As same as, depression and loss of interest after one hour at first and third day of intervention between study and control group. Conclusion: It was concluded that TENS application is effective in alleviating menstrual pain and its related symptoms. Recommendations: It is important to have safe TENS therapies for the relief of menstrual problems.
\end{abstract}

Keywords: Transcutaneous Electrical Nerve Stimulation; Menstrual symptoms; Dysmenorrhea.

\section{Introduction}

Primary dysmenorrhea (PD) is the most common gynecological symptom reported by women of reproductive age. It is defined as the recurrent, cramping pain, which occurs during menses, and lacks any identifiable reproductive system pathology. (Alghadir, A.H., Al-Eisa, E.S., Anwer, S., \& Sarkar, B. 2018). While cramping pain may be the only complaint, one or more of the following symptoms may accompany the pain: nausea, breast tenderness, diarrhea, fatigue, headache, dizziness, and more rarely, syncope and fever. PD is usually treated by pharmacological agents that are often accompanied by adverse side effects. Accordingly, integrating alternative non-pharmacological, noninvasive analgesia is preferred (Jang, S.H., Kim, D.I., \& Choi, M.S. 2014 \& Abdelmoty, H.I., Youssef, M.A., Abdallah, S., Abdel-Malak, K., 
Hashish, N.M., Samir, D., Seleem, M. 2015).

Menstrual symptoms includes affective, social and somatic symptoms that occur around the time of menses. Menstruation is the monthly shedding of the functional layer of the uterine endometrial lining that occurs when ovulation is not followed by fertilization. The average age of onset of menarche is 12.4 years, it occurs approximately every 28 days, with a range from every 21 to every 35 days. The menstrual periods last between 3 and 7 days (Herbst, A.L. 1996).. Menarche signals maturation of the adolescent female body. It commonly associated with the ability to ovulate and reproduce (Omidvar, S., \& Begum, K. 2012).

American College of Obstetrician and Gynaecologist (ACOG) put forward premenstrual tension which consists of any one of the Affective symptoms (Depression, Angry outbursts, Irritability, Anxiety, Confusion and Social withdrawal) and Somatic symptoms (Breast tenderness, Abdominal bloating, Headache and Swelling of extremities). These symptoms should occur in the three prior menstrual cycles during the 5 days before the onset of menses and the symptom must resolve within 4 days of onset of menses and not recur until after day 12 of the cycle. The symptoms must adversely affect social or work-related activities (ACOG 2013). These conditions are not life threatening but they can seriously decrease the quality of life of many adolescents and affect their mental health and their productivity (Kang,S, Lee,Y. 2013).

The main symptom of dysmenorrhea is pain concentrated in the lower abdomen or pelvis. It is also commonly felt in the right or left side of the abdomen. It may radiate to the thighs and lower back. Symptoms often co-occurring with menstrual pain include nausea and vomiting, diarrhea, headache, dizziness, disorientation, fainting and fatigue. Symptoms of dysmenorrhea often begin immediately after ovulation and can last until the end of menstruation (Abdelmoty, H.I., Youssef, M.A., Abdallah, S., Abdel-Malak, K, Hashish, N.M., Samir, D., Seleem, M. 2015). This is because dysmenorrhea is often associated with changes in hormonal levels in the body that occur with ovulation. In particular, prostaglandins induce abdominal contractions that can cause pain and gastrointestinal symptoms. The use of certain types of birth control pills can prevent the symptoms of dysmenorrhea because they stop ovulation from occurring (Iacovides, Avidon \& Baker, 2015).

Unfortunately, non-steroidal antiinflammatory drugs (NSAIDs) have been ineffective in 10 to $20 \%$ of patients with primary dysmenorrhea. Many of these drugs have been banned for various reasons, or have been reported inappropriate due to complications such as headache, nausea, dizziness, fatigue, edema, irritation and gastrointestinal discomfort ( Marjoribanks, J., Proctor, M., Farquhar, C., \& Derks, R.S. 2010). Today, there is a great tendency to use complementary and alternative medicine (CAM), and one of the applications of the CAM is the treatment of primary dysmenorrhea. Because of recent concerns about pharmacological therapy, several studies investigated the efficacy of numerous non pharmacological therapies for the relief of dysmenorrhea such as transcutaneous electrical nerve stimulation (TENS) (Iacovides, S., Avidon, I., \& Baker, F.C. 2015).

Pain relief with TENS is postulated as involving two possible mechanisms, the gate-control theory as proposed by (Parsa, P., \& Bashirian, S. 2013).or endorphinmediated pain relief. The "gate" to sensory input is present in the spinal cord, which is stimulated by activity in small-diameter nociceptive fibers and closed by activity in large-diameter fibers. Therefore, if electric stimulation is applied to a peripheral site, the large diameter fibers are activated first and thus inhibit the small nociceptive fiber input transmitted to higher centers' The "gating" 
effect is established at the dorsal horn level of the spinal cord thereby inhibiting the transmission of pain-related impulses. This mechanism is thought to be responsible for the action of high frequency TENS (Parsa, P., \& Bashirian, S. 2013).

Although there is an increased evidence for the efficacy of numerous complementary/ alternative therapies for the relief of menstrual problems, there is a little knowledge about the effect of different therapies, such as thermotherapy, acupuncture as well as Transcutaneous Electrical Nerve Stimulation (TENS) for management of dysmenorrhea among adolescent girls (Jang, Kim \& Choi, 2014).

\section{Aim of the Study}

This study aims to explore the effect of Transcutaneous Electrical Nerve Stimulation (TENS) on menstrual symptoms among adolescent girls.

\section{Research Hypothesis}

Adolescent girls who receive Transcutaneous Electrical Nerve Stimulation (TENS) exhibit reduced severity of menstrual symptoms than those who do not receive it.

\section{Materials and Method}

\section{Materials}

Design: A non-randomized (single blind) controlled clinical trial research design was adopted.

Setting: The study was conducted at the Technical Institute of Nursing named "Dar Ismail" affiliated to the Ministry of Health and Population in Alexandria city.

Subjects: The study was comprised a purposive sample of 100 female students in the first \& second years Technical Institute of Nursing. They were surveyed to pin point those who suffer from moderate to severe primary dysmenorrhea (PD). Students were eligible to participate in the study, if they were single, aged 15-19 year-old at the time of the study, with regular cycles 21 to 35 days, don't receiving analgesics or hormonal replacement therapy during the last 6 months and had no systemic or gynecologic disease during the study period.

Then each of the 100 students were assigned to either the control or the study group, 50 students are included in each group. The study group had receive TranseCutaneous Electrical Nerve Stimulation (TENS) while, control group received TENS sham.

Tools: Three tools were used for data collection:

\section{Tool I: Students' Basic Data Structured Interview Schedule}

It was developed by the researcher to collect the necessary data from female students. It will include three parts:

Part (1): Socio-demographic characteristics and clinical data of the adolescents such as; age, religion, telephone number.

Part (2): Students' physical health status, it contains data about weight, height to collect BMI, past health history, previous and current medical or gynecological health complaints and/ or medication use.

Part (3): Students' menstrual history, such as age at menarche, interval, duration and frequency of menstruation as well as amount of blood flow, the presence, frequency and severity of dysmenorrhea and its associated symptoms.

\section{Tool II: Visual Analog Scale}

It was originally developed by Katz and Melzack (1999). This tool will be adopted \& translated into Arabic language by the researcher and tested for its reliability \& validity. It was used by the researcher to determine the severity of pain before and after intervention. It is a self- reported $10 \mathrm{~cm}$ straight line which represents the pain intensity, the two opposite ends representing no pain to pain as bad as it could be in between these two phrases, words like mild pain, moderate pain, severe pain, very severe 
pain are assigned to each $2 \mathrm{~cm}$ distance respectively.

\section{Tool III: Menstrual symptom questionnaire (MSQ)}

It was developed by Negriff et al. (2009). It was adopted and used by the researcher to assess the physical and psychological symptoms that associated with menstrual symptoms. It entails 7 items, for each item the subject has to choose one of four alternatives: (0) absent, (1) mild, (2) moderate, or (3) severe. Total score was range from 0 to 21 . The subject will be considered to have:

- No dysmenorrheal symptom (DS) if her total score $<6$.

- Mild DS if her total score 6-11.

- Moderate DS if her total score 12-17.

- Severe DS if her total score $>17$.

\section{Method}

- Approval was obtained from the Ethical Committee of the faculty of nursing- Alexandria University and then from responsible authorities of the study setting. Then, the researcher attended a training workshop on how to conduct Transcutaneous Electrical Nerve Stimulation (TENS).

- Development of tools: Tool II \& III were adopted, translated into Arabic and the necessary modifications were done. Tools content validity was assessed by a jury of 5 experts in the related field. Tool III reliability was accomplished by split half reliability technique. It has high internal consistency with (Cronbach's alphas $=$ 0.826 )

- A pilot study was carried out on 10 students to ascertain the clarity and applicability of the tools and calculate the time needed to its completion.

- The study was conducted through three phases:

\section{Preparation phase:}

- All female students in first \& second years in the previously mentioned setting given a proper explanation about the study purpose, design, and subject's role. The explanation was done using power point presentation at classroom for small group (15-20) students every session. Then they were individually interviewed by the researcher to collect the necessary data using (tool 1)

\section{The screening phase:}

- The researcher screen all female students for moderate to severe primary dysmenorrhea and its associated symptoms during menstrual cycle using tools (II\&III). Those who were diagnosed as moderate to severe PD and meet the eligible criteria were included in the study. Detailed explanation about MS and its management especially the effect and technique of TENS was applied. Subjects were allocated to two groups 50 for each of them. Study group, received TENS unit while control group received TENS sham.

\section{The implementation phase:}

- The subjects in the experimental group was placed in supine lying in a comfortable position as possible. The abdomen to the inguinal region was decently exposed, cleaned using methylated spirit and cotton wool for electrode placement, after inspection of the area for cuts, skin infections or any abnormalities. The absence of such skin conditions as well as intact skin sensation indicates suitability for further procedures. A pair of electrodes (inactive electrodes) was placed a little below the umbilicus (Right and Left) and the other pair (active electrode) along the inguinal region at the level of pubic symphysis (Right and Left). A quadripolar 
method that used for placement of electrode.

- Then a high - frequency TENS Hz, 200 unit pulse duration, and intensity up will be set at frequency 100-120 $\mathrm{mA}$. to 50 Electrical current was gradually increased till a pleasant tingling sensation is felt by the student. The duration of TENS application was 30 minutes.

- While, the subjects in the control group "TENS sham group', TENS unit electrodes was applied in the previously mentioned area on the skin, while it was off (no current output).

\section{Evaluation phase:}

- $\quad$ Both groups was assessed during $1^{\text {st }} \&$ $3^{\text {rd }} \& 5^{\text {th }}$ days of menstruation for menstrual symptoms using tool II and III for three times: before TENS and sham application, 60 minutes after each TENS and sham application.

- Study subject in both groups was asked to record the pre - post TENS measurement at logbook after each application. Items in the logbook included location of pain, intensity of pain and MS, before and after application, stimulation duration, and side effect.

- Comparison between the differences in pain relief among the two groups and within the same group that done by the suitable statistical analysis.

\section{Ethical considerations:}

- Subject was voluntary participate in the study.

- Written informed consent was obtained from every participant / guardian included in the study after explanation of its aim and assuring them that collected data was used only for the study purpose.

- The anonymity and confidentiality of subject's responses was maintained
- Subject has the right to withdraw from the study was emphasized.

- Subject privacy during data collection and Transe-cutaneous Electrical Nerve Stimulation intervention was maintained.

\section{Statistical Analysis}

Data were fed to the computer and analyzed using IBM SPSS software package version 20.0. (Armonk, NY: IBM Corp) (Kirkpatrick \& Feeney, 2013). Qualitative data were described using number and percent. Quantitative data were described using range (minimum and maximum), mean, and standard deviation. Significance of the obtained results was judged at the $5 \%$ level.

\section{The used tests were:}

1- Chi-square test: For categorical variables, to compare between different groups.

2- Fisher's Exact or Monte Carlo correction: Correction for chi-square when more than $20 \%$ of the cells have expected count less than 5 .

3 - Student t-test: For normally distributed quantitative variables, to compare between two studied groups.

\section{Results}

Table (1) indicates no significant differences between the study and control groups regarding their Demographic characteristics. Where, more than half $(52.0 \% \& 52.5 \%)$ respectively of both study group and control group were in the first and second academic year, while $72.5 \%$ of the study group were in the fourth academic one. Two-thirds $(60.0 \%)$ of the study group were 17 years old or less, compared to $66.0 \%$ control group. Vast majority of the study group (94.0\%) and all of control group were urban residents. Regarding family's income, about or more than half $(52.0 \%$ \& $50.0 \%$ ) of study and control group their families' Hardly had enough income.

Concerning, crowding index, there is no significant difference between mean \pm SD 
$1.81 \pm 0.33$ of study compared to mean $\pm \mathrm{SD}$ $1.83 \pm 0.38$ of control group $(\mathrm{P}=0.763)$.

According to table (2), the majority (70.0 \% \& 60.0\% respectively) of the study and control group had moderate primary dysmenorrheal (PD) before the intervention with no statistically significant difference between them. Close percentages $(58.0 \%$ and $50.0 \%$ ) of the study and control groups, respectively, had experienced the pain at lower abdomen.

The character of pain was deep and continuous in $40.0 \%$ of the study and/or control groups. The associated systemic symptoms was $66.0 \%$ and $82.0 \%$ among study and control groups, respectively specifically, Headache, Abdominal pain, Anorexia and Exhaustion. Only 9.1\% and 9.8\% from the study and control groups respectively had depression symptoms.

According to table (3), all of study group had suffered from dysmenorrheal pain before the intervention. Specifically, $40.0 \%$ and $60.0 \%$ of them had either severe or very sever pain, respectively. During the first day, after 30 minutes from the intervention the picture improved, pain was still present, yet in a different profile. Where $64.0 \%$ of study group had moderate pain compared to $30.0 \% \& 6.0 \%$ of them respectively had sever or very severe pain the difference was a statistically significant $(\mathrm{P}<0.01)$. At Third day, the picture further improved after intervention, where $14.0 \%$ of study group had mild pain and about two thirds $(60.0 \%)$ had moderate pain and non of them had worst pain compared to $74.0 \%$ had sever pain before intervention the difference was statistically significant $(\mathrm{P}<0.01)$. By the Fifth day from the intervention, $74.0 \%$ of study group had mild pain compared to non of them had sever or very sever pain the difference was statistically significant $(\mathrm{P}<0.001)$.

Table (4) shows that the entire control group had suffered from pain before the intervention at the first day of menstruation. Specifically, $46 \%$ and $54 \%$ of control group before Sham TENS 'placebo' compared to $56 \%$ and $30 \%$ of them after 60 minutes of placebo had either severe or very sever pain, respectively. The difference was statistically significant $(\mathrm{P}<0.001)$. At third day, from the intervention, pain was slightly improved among control group, yet in a different profile. Where $74.0 \%$ \& $26.0 \%$ had either severe or very severe pain before Sham TENS 'placebo' compared to $58.0 \%$ and $42.0 \%$ of them after 30 minutes of placebo had either moderate or severe pain, respectively.

Again, at fifth day $44.0 \%$ and $52.0 \%$ of control group had either moderate or sever pain before Sham TENS 'placebo', pain was slightly improved among $60.0 \%$ and $32.0 \%$ of them, the pain profile was slightly improved to be mild or moderate, In general, there was a statistically significant differences between pain intensity before and after 'placebo' at $1^{\text {st }}, 3^{\text {rd }}$ and $5^{\text {th }}$ day that equal $(\mathrm{P}<0.001)$ for all days.

Table (5) exhibits that $40 \%$ \& $60 \%$ of the study and $46 \% \& 54 \%$ of control groups had severe or very sever pain before the intervention with no statistically significant difference between them $(\mathrm{P}<0.545)$. At first day after intervention, there was a statistically significant difference $(\mathrm{P}<0.004)$ between the study and control groups in favor of the former. Where only $6 \%$ of the study group had worst pain compared to as much as $30 \%$ of the control group.

At third day, there was no statistically significant difference $(\mathrm{P}=1.000)$ between the two group before intervention. Where, an equal percent $74 \%$ \& $26 \%$ either for the study and control group had severe or worst pain. Again, after 30 minutes, a statistically significant difference $(\mathrm{P}=0.009)$ had reappeared between the two groups in the favor of the study group. Where only $26 \%$ of the study group had severe pain compared to $42.0 \%$ of the control group.

Such difference had persisted at fifth day after intervention, where pain was completely absent or become mild in 
$14.0 \% \& 74.0 \%$ of the study group compared to $8.0 \%$ \& $60 \%$ of the control group. There was a statistically significant difference $(\mathrm{P}=0.047)$ between the two groups after 30 minutes of intervention.

Table (6a) denotes a statistically significant difference at first day of menstruation regarding the severity of physical symptoms as nausea and vomiting \& Dizziness \& Tired and Headache among study group where $(7 \% \& 43 \%) \&$ $(26 \% \& 7 \%) \&(3 \% \& 13 \%) \&(18 \% \& 17 \%)$ had moderate to severe before and mild to moderate $(11 \% \& 36 \%) \&$ non to mild $(34 \% \& 5 \%) \&(34 \% \& 3 \%) \&(27 \% \& 3 \%)$ after 60 minutes of intervention $(p=0.001) \&$ $(\mathrm{p}=0.001) \quad \& \quad(\mathrm{p}=0.001) \quad \& \quad(\mathrm{p}=0.001)$ respectively.

This symptom had the same pervious pattern, at third and fifth day $(22 \% \& 22 \%)$ $\&(30 \% \& 4 \%)$ for nausea and vomiting \& $(10 \% \& 10 \%) \&(3 \% \& 0 \%)$ for Dizziness \& $(10 \% \& 3 \%) \&(6 \% \& 0 \%)$ for Tired \& $(16 \%$ $\& 7 \%) \&(10 \% \& 0 \%)$ for Headache at 30 minutes of intervention had either mild or moderate pain. There was a statistically significant differences at third day $(\mathrm{p}<0.001 \& \mathrm{p}<0.001 \& \mathrm{p}<0.001 \& \mathrm{p}=0.002)$. At fifth day $(\mathrm{p}<0.001 \& \mathrm{p}<0.001 \& \mathrm{p}<0.001$ and $\mathrm{p}<0.001)$ respectively.

Table (6b) denotes the severity of psychological symptom among the study group. There was statistically significant differences $(\mathrm{p}=0.003, \& \mathrm{p}=0.008)$ between the severity of these symptoms before and after intervention. Where, $(17 \% \& 9 \%)$ had severe depression, loss of interest before intervention at first day compared to, (8\%\&2\%) after intervention respectively.

On the other hand, there was a statistically significant difference in the severity of depression, loss of interest and a sense of uselessness before and after one hours at third and fifth day of intervention $(\mathrm{p}=0.001 \quad \& \quad \mathrm{p}=0.0033 \quad \& \quad \mathrm{p}=0.005)$ respectively.

Regarding the severity of physical symptoms among control group, table (7a) indicates no statistically significant differences $\left(p=0.046^{*}, \& p=0.117,0.655\right)$ between the severity of dizziness, tired and headache among the control group before and after 1 hours, at first day of the intervention (TENS sham respectively. At third and fifth day the picture was completely different. Where the percent of severe dizziness, tired and headache had decreased respectively at third day the difference was statistically significant $(\mathrm{p}=0.007 \& \mathrm{p}=0.00 \& 0.001)$. While, none of them had severe before and after fifth day from the intervention (TENS sham) respectively. On the other hand, there was a statistically significant differences $(p=0.001 \& p=0.011 \& 0.001)$ between the severity of nausea and vomiting among control group before and after 1 hours, at first, third and fifth day of the intervention (TENS sham respectively.

As regards to severity of psychological symptom among the control group, table (7b) indicates statistically significant differences between the severity of depression and sense of uselessness symptoms before and 1 hour after at first third and fifth day intervention (TENS sham) $(\mathrm{p}=0.006, \& \mathrm{p}=0.001 \& \mathrm{p}=0.005) \&$ $(\mathrm{p}=0.014 \quad \& \quad \mathrm{p}=0.014 \quad \& \quad \mathrm{p}=0.001)$ respectively.

On the other hand, there was no statistically significant difference in the severity of loss of interest before and after one hours at first and third day of intervention $(\mathrm{p}=0.157 \quad$ \& $\quad \mathrm{p}=0.180)$ respectively. While, there is a statistically significant difference at fifth day of intervention $(\mathrm{p}=0.001)$.

Table (8a) represents the number and percent distribution of physical symptoms among study \& control groups according to the severity of associated nausea and vomiting, As much as $(86.0 \%$ \& $32.0 \%$ \& $00.0 \%)$ of the study compare to $(92.0 \%$ \& $38.0 \%$ \& $00.0 \%$ ) respectively of the control group had sever nausea and vomiting before the intervention at first $\&$ third and fifth day with no statistically significant difference 
between them $(\mathrm{P}=0.338 \& 0.713 \& 0.576)$ respectively. At first third and fifth day from the intervention, there was a statistically significant difference $(\mathrm{p}=0.043 \& \mathrm{p}=0.001 \&$ $\mathrm{p}=0.001$ ) between the study and control group in favor of the former one.

On the other hands, the results of this study showed that, there is no statistically significant differences $(\mathrm{p}=0.218 \quad \&$ $\mathrm{p}=0.153 \& \mathrm{p}=0.062)$ between the severity of dizziness, tired and headache among study and control group at first day before intervention (TENS sham respectively. After first and third day, the picture was completely different. Where there is a statistically significant differences $(\mathrm{p}=0.001 \& \mathrm{p}=0.004) \&(\mathrm{p}=0.040 \& \mathrm{p}=0.003)$ between the severity of dizziness and tired among study and control group respectively. On the other hand, there is no statistically significant differences regarding feeling of headache $(p=0.687 \& p=0.687 \& p=0.687)$ at first and third and fifth day compare to one hours after intervention respectively.

As regards the severity of psychological symptom among study and control group, table (8b) indicates no statistically significant differences between the severity of depression \& loss of interest and sense of uselessness symptoms before a first, third and fifth day intervention (TENS sham) $(\mathrm{p}=0.0 .894, \quad \& \mathrm{p}=0.461 \quad \& \mathrm{p}=0.611) \&$ $(\mathrm{p}=0.014 \& \quad \mathrm{p}=0.014 \quad \& \quad \mathrm{p}=0.001)$ respectively.

On the other hand, there was statistically significant difference in the severity of depression after one hours at first and third day of intervention between study and control group $(\mathrm{p}=0.014 \& \quad \mathrm{p}=0.0 .001)$ respectively. While, there is no statistically significant difference at first and fifth day of intervention $(p=0.015 \& p=0.012)$. On the other hand, there is no significant difference at first third and fifth day of intervention between study and control group regarding sense of uselessness.

\section{Discussion}

Dysmenorrhea is a disorder characterized by lower abdominal pain that occurs during menstruation, however, the pain may start 2 or more days before it. It is sometimes associated with headache, nausea, vomiting, diffuse abdominal pain, backache, general malaise, weakness, and other gastrointestinal symptoms (Alghadir, A.H., Al-Eisa, E.S., Anwer, S., \& Sarkar, B. 2018). It is classified into two categories: primary and secondary. Primary dysmenorrhea (PD) is a common gynecological complaint that may affect as many as $50 \%$ of women. Although there is an increased evidence for the efficacy of numerous complementary/ alternative therapies for the relief of menstrual problems, there is a little knowledge about the effect of different therapies, such as thermotherapy, acupuncture as well as transcutaneous electrical nerve stimulation (TENS)for management of dysmenorrhea among adolescent girls (Davis AR, Westhoff C, O'Connell K, Gallagher N. 2005).

This study examined the effectiveness of conventional TENS on primary dysmenorrhea. There was a notable meaningful reduction in pain intensity after comparing pre-treatment and post- treatment values in the TENS group. This indicates that conventional TENS is an appropriate method for reducing primary dysmenorrhea.

On investigating the effect of Transcutaneous Electrical Nerve Stimulation (TENS) on primary dysmenorrhea (PD) among adolescent girls (study group). The result of the present study revealed that the severity of PD were significantly changed from either severe or very severe before the intervention to mild or moderate among study 1 st \& 3rd \& 5th of menstrual cycle after 30 minutes of intervention. This result is congruent with Bai HY et al. (2017) who study the effect of Transcutaneous Electrical Nerve Stimulation Therapy for the treatment of primary dysmenorrheal. He concluded that, TENS was efficacious and safe in relieving pain in participants with PD. 
Moreover, Lauretti GR et al. (2015) proved that portable active TENS device induced a prompt onset of pain relief and improved the quality of life, without adverse effects, in patients with painful cramps associated with dysmenorrhea. In addition, Arik MI et al. (2020) TENS is a safe and well-tolerated electro physical therapy that may be effective for relieving pain in PD.

The result of this study showed statistically significant differences between the pain intensity among control group before and after 30 minutes on the first, third and fifth days of received the "placebo" sham TENS, which equals $(\mathrm{P}<0.001)$ for all days. These results were in consistent with the results of Parsa P and Bashirian S(2013) they reported that there is a decrease in pain intensity after TENS and placebo TENS were both significant, (Active group: $\mathrm{p}<0.01$; placebo group:, $\mathrm{p}<0.01)$. However, pain intensity in active TENS was significantly decreased than the placebo group $(\mathrm{p}=0.000)$. On the other hands these results are inconsistent with Dawood MY and Ramos J (1990) who reported that dysmenorrheal pain relieves in only $3.2 \%$ of the control group with placebo TENS.

As regarding the effect of Transcutaneous Electrical Nerve Stimulation (TENS), on primary dysmenorrhea among study group compare to placebo group (control group). The result of the present study revealed that the severity of PD (menstrual pain) were significantly changed from either severe or worst sever pain before the intervention to mild among study than control group, after the intervention. This result is congruent with Elboim-Gabyzon M and Kalichman L ((2020)who found that (TENS) PD occurs only during ovulatory cycles due to excessive secretion of prostaglandins and decreased ovarian steroid hormone levels in the endometrium as causes of PD. These changes result in hyper contractility of the uterus that lasts for hours with possible elevated intrauterine pressure and decreased blood flow, and leads to uterine hypoxia and ischemia, which are believed to cause the underlying etiologies for the pain and cramps.

Vasodilation that altered by TENS, increased blood flow, and menstrual fluid prostaglandins, and indirectly allowed analgesic effects. These effects are probably mediated by the inhibition of nociceptive fiber-evoked responses in the dorsal horn. Based on the gate control theory of pain, this inhibition is caused by stimulation of large diameter afferents which are stimulated by TENS.15 Sensory stimulation of the skin may also cause local vasodilation in the same dermatome via axonal reflexes. The effects of TENS are also modulated by anatomic pathways, opioid release, decreased release of prostaglandins, and possibly eicosanoids that are released from the endometrium during menstruation following antidromic blockage of nerve fibers with large diameters Arik M.I, Kiloatar,H, Aslan B, Icelli M.(2020).

Furthermore, of Parsa P and Bashirian S (2013) shown improvement in pain through both TENS and placebo TENS. Although, the mechanisms of TENS and placebo TENS in pain relief are different. The mechanism of high-frequency TENS in pain relief is based on gate-control theory or axonal reflex to make vessels around the local organ dilate by stimulating the peripheral nerves. Meanwhile, the mechanism of placebo TENS on pain relief seems to be through the release of endorphin. A previous study showed placebo stimulation and endorphin injection had similar reactions over the cortex area and brainstem for relief the pain

The results of the present study denotes a statistically significant reduced the incidence and severity of nausea and vomiting \& dizziness \& tired and headache among study group from moderate to sever before intervention to mild to moderate 30 minutes after intervention at first day of menstruation. This symptom had the same pervious pattern, at third and fifth day of intervention. As same as the results of Parsa P and Bashirian S (2013) they indicate that 
active TENS is effective in reducing dysmenorrheal symptoms beside there is no adverse effects were observed. In addition, Dawood and Ramos J (1990) demonstrated that TENS provided good to excellent subjective menstrual symptoms relief as reduced diarrhea, clot formation, and fatigue.

As regards to severity of psychological symptom that associated with primary dysmenorrhea, a sizable proportion of TENS group reported absence or presence of mild symptoms than placebo TENS group, one and two months after the intervention.. There was statistically significant difference in the severity of depression after one hour at first and third day of intervention between study and control group Ojoawo OA, Esan $O$ and Oloni DA (2020) TENS affecting their quality of life but also reducing productivity. In addition to its interference with daily function and its impact on the physical and emotional conditions, it negatively influences academic and daily activities. Ovulation increases the production of fatty acids, which is the precursor for the production of prostaglandins; the implication is that women who do not ovulate, may not experience cramps and primary dysmenorrhea. Therefore, primary dysmenorrhea can be treated by inhibiting ovulation with oral contraceptives. While these results is not with Bai, Hai-Yan MB, et al. (2017) These results indicate the promising effect of TENS for pain relief in participants with PD, although no encouraging improvement was found in the quality of life, as measured by the WHOQOL-BREF scores. On the other hand, Elboim-Gabyzon $\mathrm{M}$ and Kalichman $\mathrm{L}$ (2020) concluded from Their review presents the clinical recommendations for TENS parameters for treating primary dysmenorrhea symptoms and added that, The evoked results of previous studies demonstrated the positive effects of TENS in reducing pain and related PD symptoms, and improvement of the quality of life.

\section{Conclusion}

It could be concluded that TENS application is effective in alleviating menstrual pain and its related symptoms.

\section{Recommendations}

According to this study, these recommendations are suggested:

- In service training program should be carried out for nurses who are working in Technical Institute of Nursing to upgrade their knowledge regarding the importance of (TENS) on menstrual health.

- It is important to have safe and efficacy of TENS therapies for the relief of menstrual problems.

- Nurses encouraging adolescents to discuss menstrual concerns. Including use of complementary therapy.

- Further researches to be carried out to investigate barriers against practicing of TENS management of menstrual symptoms. 
Table (1): Number and percent distribution of the study subjects according to their sociodemographic characteristics

\begin{tabular}{|c|c|c|c|c|c|c|c|}
\hline \multirow{2}{*}{ Q } & \multirow{2}{*}{$\begin{array}{l}\text { Demographic characteristics of } \\
\text { the adolescents }\end{array}$} & \multicolumn{2}{|c|}{$\begin{array}{c}\text { Study } \\
(\mathbf{n}=\mathbf{5 0})\end{array}$} & \multicolumn{2}{|c|}{$\begin{array}{l}\text { Control } \\
(\mathbf{n}=\mathbf{5 0})\end{array}$} & \multirow{2}{*}{$\begin{array}{l}\text { Test of } \\
\text { Sig. }\end{array}$} & \multirow{2}{*}{$\mathbf{p}$} \\
\hline & & No. & $\%$ & No. & $\%$ & & \\
\hline & $\begin{array}{l}\text { Grade } \\
\text { First } \\
\text { Second }\end{array}$ & $\begin{array}{l}24 \\
26\end{array}$ & $\begin{array}{l}48.0 \\
52.0\end{array}$ & $\begin{array}{l}26 \\
24\end{array}$ & $\begin{array}{l}52.0 \\
48.0\end{array}$ & $\chi^{2}=1.847$ & 0.397 \\
\hline 1 & $\begin{array}{c}\begin{array}{c}\text { Age in years } \\
\leq 17 \\
18-19\end{array}\end{array}$ & $\begin{array}{l}30 \\
20\end{array}$ & $\begin{array}{l}60.0 \\
40.0\end{array}$ & $\begin{array}{l}33 \\
17\end{array}$ & $\begin{array}{l}66.0 \\
34.0\end{array}$ & $\chi^{2}=0.386$ & 0.534 \\
\hline & $\begin{array}{l}\text { Min. - Max. } \\
\text { Mean } \pm \text { SD. }\end{array}$ & \multicolumn{2}{|c|}{$\begin{array}{c}15.0-19.0 \\
17.04 \pm 1.14\end{array}$} & \multicolumn{2}{|c|}{$\begin{array}{c}15.0-19.0 \\
16.92 \pm 1.05\end{array}$} & $\mathrm{t}=0.548$ & 0.585 \\
\hline 2 & $\begin{array}{l}\text { Religion } \\
\text { Muslim } \\
\text { Christian } \\
\end{array}$ & $\begin{array}{c}46 \\
4\end{array}$ & $\begin{array}{c}92.0 \\
8.0\end{array}$ & $\begin{array}{c}47 \\
3\end{array}$ & $\begin{array}{c}94.0 \\
6.0\end{array}$ & $\chi^{2}=0.154$ & ${ }^{\mathrm{FE}} \mathrm{p}=1.000$ \\
\hline 4 & $\begin{array}{l}\text { Residence } \\
\text { Rural } \\
\text { Urban }\end{array}$ & $\begin{array}{c}3 \\
47 \\
\end{array}$ & $\begin{array}{c}6.0 \\
94.0\end{array}$ & $\begin{array}{c}0 \\
50\end{array}$ & $\begin{array}{c}0.0 \\
100.0\end{array}$ & $\chi^{2}=3.093$ & ${ }^{\mathrm{FE}} \mathrm{p}=0.242$ \\
\hline 5 & $\begin{array}{l}\text { Income } \\
\text { Enough and more } \\
\text { Hardly enough } \\
\text { Not enough }\end{array}$ & $\begin{array}{l}10 \\
26 \\
14\end{array}$ & $\begin{array}{l}20.0 \\
52.0 \\
28.0\end{array}$ & $\begin{array}{l}15 \\
25 \\
10\end{array}$ & $\begin{array}{l}30.0 \\
50.0 \\
20.0\end{array}$ & 1.686 & 0.430 \\
\hline 6 & $\begin{array}{l}\text { No. of family members } \\
\text { Min. - Max. } \\
\text { Mean } \pm \text { SD. } \\
\end{array}$ & \multicolumn{2}{|c|}{$\begin{array}{c}4.0-6.0 \\
4.74 \pm 0.69\end{array}$} & \multicolumn{2}{|c|}{$\begin{aligned} & 3.0-6.0 \\
& 4.68 \pm 0.79 \\
&\end{aligned}$} & $\mathrm{t}=0.402$ & 0.688 \\
\hline 7 & $\begin{array}{l}\text { No. of rooms } \\
\text { Min. - Max. } \\
\text { Mean } \pm \text { SD. } \\
\end{array}$ & \multicolumn{2}{|c|}{$\begin{array}{c}2.0-4.0 \\
2.70 \pm 0.58\end{array}$} & \multicolumn{2}{|c|}{$\begin{aligned} 2.0 & -3.0 \\
2.62 & \pm 0.49\end{aligned}$} & $\mathrm{t}=0.745$ & 0.458 \\
\hline 8 & $\begin{array}{l}\text { Crowding index } \\
\text { Min. - Max. } \\
\text { Mean } \pm \text { SD. } \\
\end{array}$ & \multicolumn{2}{|c|}{$\begin{array}{l}1.25-2.50 \\
1.81 \pm 0.33\end{array}$} & \multicolumn{2}{|c|}{$\begin{array}{l}1.33-2.50 \\
1.83 \pm 0.38 \\
\end{array}$} & $\mathrm{t}=0.303$ & 0.763 \\
\hline
\end{tabular}

Significant $p$ at $\leq 0.05$ 
Table (2): Number and percent distribution of the study subjects according to their history of primary dysmenorrhea

\begin{tabular}{|c|c|c|c|c|c|c|c|}
\hline \multirow{2}{*}{$\mathbf{Q}$} & \multirow{2}{*}{ History of primary dysmenorrhea } & \multicolumn{2}{|c|}{ Study $(\mathbf{n}=50)$} & \multicolumn{2}{|c|}{ Control $(n=50)$} & \multirow{2}{*}{$\chi^{2}$} & \multirow{2}{*}{$\mathbf{p}$} \\
\hline & & No. & $\%$ & No. & $\%$ & & \\
\hline \multirow[t]{5}{*}{22} & \begin{tabular}{|c|} 
Pain during menses \\
Yes \\
No \\
\end{tabular} & $\begin{array}{c}50 \\
0 \\
\end{array}$ & $\begin{array}{c}100.0 \\
0.0 \\
\end{array}$ & $\begin{array}{c}50 \\
0 \\
\end{array}$ & $\begin{array}{c}100.0 \\
0.0 \\
\end{array}$ & - & - \\
\hline & \begin{tabular}{|l} 
Pain intensity \\
Mild \\
Moderate \\
Severe
\end{tabular} & $\begin{array}{c}0 \\
35 \\
15\end{array}$ & $\begin{array}{c}0.0 \\
70.0 \\
30.0\end{array}$ & $\begin{array}{c}0 \\
30 \\
20\end{array}$ & $\begin{array}{c}0.0 \\
60.0 \\
40.0\end{array}$ & 1.099 & 0.295 \\
\hline & \begin{tabular}{|l} 
Character of pain \\
Deep and continuous pain \\
Cutting pain \\
Sharp and severe pain \\
Spastic pain \\
Unclear pain
\end{tabular} & $\begin{array}{c}20 \\
10 \\
6 \\
7 \\
7\end{array}$ & $\begin{array}{l}40.0 \\
20.0 \\
12.0 \\
14.0 \\
14.0\end{array}$ & $\begin{array}{c}20 \\
11 \\
12 \\
3 \\
4\end{array}$ & $\begin{array}{c}40.0 \\
22.0 \\
24.0 \\
6.0 \\
8.0\end{array}$ & 4.466 & 0.347 \\
\hline & $\begin{array}{l}\text { Site of the pain } \\
\text { Lower abdomen only } \\
\text { Back } \\
\text { On the thighs } \\
\text { All of the above } \\
\text { Another }\end{array}$ & $\begin{array}{c}29 \\
9 \\
3 \\
18 \\
0\end{array}$ & $\begin{array}{c}58.0 \\
18.0 \\
6.0 \\
36.0 \\
0.0\end{array}$ & $\begin{array}{c}25 \\
13 \\
0 \\
19 \\
4\end{array}$ & $\begin{array}{c}50.0 \\
26.0 \\
.0 \\
38.0 \\
8.0\end{array}$ & $\begin{array}{l}0.644 \\
0.932 \\
3.093 \\
0.043 \\
4.167^{*}\end{array}$ & $\begin{array}{c}0.422 \\
0.334 \\
\mathrm{FE}_{\mathrm{p}}=0.242 \\
0.836 \\
\mathrm{FE}_{\mathrm{p}}=0.117\end{array}$ \\
\hline & $\begin{array}{l}\text { Pain duration } \\
\text { First day } \\
1^{\text {st }} \text { t \& } 2^{\text {nd }} \text { day } \\
1^{\text {st }} \& 2^{\text {nd }} \& 3^{\text {rd }} \text { day }\end{array}$ & $\begin{array}{c}13 \\
8 \\
29\end{array}$ & $\begin{array}{l}26.0 \\
16.0 \\
16.0\end{array}$ & $\begin{array}{c}6 \\
17 \\
27\end{array}$ & $\begin{array}{l}12.0 \\
34.0 \\
54.0\end{array}$ & 5.890 & 0.053 \\
\hline \multirow[t]{2}{*}{23} & $\begin{array}{l}\text { Associated symptoms } \\
\text { Yes } \\
\text { No }\end{array}$ & $\begin{array}{l}33 \\
17\end{array}$ & $\begin{array}{l}66.0 \\
34.0\end{array}$ & $\begin{array}{c}41 \\
9\end{array}$ & $\begin{array}{l}\mathbf{8 2 . 0} \\
18.0\end{array}$ & 3.326 & 0.068 \\
\hline & $\begin{array}{l}\text { If yes, what are these symptoms? } \\
\text { Headache } \\
\text { Exhaustion } \\
\text { Abdominal pain } \\
\text { Anorexia } \\
\text { Leg pain } \\
\text { Dizziness } \\
\text { Depression } \\
\text { Nausea } \\
\text { Back pain } \\
\text { All of the above }\end{array}$ & $\begin{array}{l}10 \\
7 \\
9 \\
7 \\
3 \\
6 \\
3 \\
3 \\
0 \\
4\end{array}$ & $\begin{array}{c}30.3 \\
21.2 \\
27.3 \\
21.2 \\
9.1 \\
18.2 \\
9.1 \\
9.1 \\
0.0 \\
12.1\end{array}$ & $\begin{array}{c}18 \\
4 \\
24 \\
4 \\
0 \\
10 \\
4 \\
7 \\
12 \\
0\end{array}$ & $\begin{array}{c}43.9 \\
9.8 \\
58.5 \\
9.8 \\
0.0 \\
24.4 \\
9.8 \\
17.1 \\
29.3 \\
0.0\end{array}$ & $\begin{array}{c}1.438 \\
1.896 \\
7.233^{*} \\
1.896 \\
3.885 \\
0.416 \\
0.009 \\
0.997 \\
11.528^{*} \\
5.254^{*}\end{array}$ & $\begin{array}{c}0.231 \\
\mathrm{FE}_{\mathrm{p}}=0.201 \\
0.007^{*} \\
\mathrm{FE}_{\mathrm{p}}=0.201 \\
\mathrm{HE}_{\mathrm{p}}=0.084 \\
0.519 \\
\mathrm{FE}_{\mathrm{p}}=1.000 \\
\mathrm{FE}_{\mathrm{p}}=0.496 \\
0.001^{*} \\
\mathrm{FE}_{\mathrm{p}}=0.036\end{array}$ \\
\hline
\end{tabular}

Significant $p$ at $\leq 0.05$

Table (3): Number and percent distribution of the study group according to their pain intensity before and after the intervention at different periods first month $(n=50)$

\begin{tabular}{|c|c|c|c|c|c|c|c|c|c|c|c|c|}
\hline \multirow{4}{*}{$\begin{array}{l}\text { Menstrual pain } \\
\text { intensity }\end{array}$} & \multicolumn{12}{|c|}{ Study $(n=50)$} \\
\hline & \multicolumn{4}{|c|}{ First day } & \multicolumn{4}{|c|}{ Third day } & \multicolumn{4}{|c|}{ Fifth day } \\
\hline & \multicolumn{2}{|c|}{ Pre } & \multicolumn{2}{|c|}{ Post } & \multicolumn{2}{|c|}{ Pre } & \multicolumn{2}{|c|}{ Post } & \multicolumn{2}{|c|}{ Pre } & \multicolumn{2}{|c|}{ Post } \\
\hline & No. & $\%$ & No. & $\%$ & No. & $\%$ & No. & $\%$ & No. & $\%$ & No. & $\%$ \\
\hline No pain & 0 & 0.0 & 0 & 0.0 & 0 & 0.0 & 0 & 0.0 & 0 & 0.0 & 7 & 14.0 \\
\hline Mild pain & 0 & 0.0 & 0 & 0.0 & 0 & 0.0 & 7 & 14.0 & 3 & 6.0 & 37 & 74.0 \\
\hline Moderate pain & 0 & 0.0 & 15 & 64.0 & 0 & 0.0 & 30 & 60.0 & 24 & 48.0 & 6 & 12.0 \\
\hline Severe pain & 20 & 40.0 & 32 & 30.0 & 37 & 74.0 & 13 & 26.0 & 20 & 40.0 & 0 & 0.0 \\
\hline Worst pain & 30 & 60.0 & 3 & 6.0 & 13 & 26.0 & 0 & 0.0 & 3 & 6.0 & 0 & 0.0 \\
\hline MH (p) & \multicolumn{4}{|c|}{$174.0^{*}\left(<0.001^{*}\right)$} & \multicolumn{4}{|c|}{$132.50^{*}\left(<0.001^{*}\right)$} & \multicolumn{4}{|c|}{$95.0^{*}\left(<0.001^{*}\right)$} \\
\hline Mean \pm SD. & 9.32 & & & 1.44 & 8.62 & 1.19 & 5.4 & 1.76 & 6.34 & $=1.71$ & 1.9 & 1.35 \\
\hline $\mathbf{t}(\mathbf{p})$ & \multicolumn{4}{|c|}{$14.965^{*}\left(<0.001^{*}\right)$} & \multicolumn{4}{|c|}{$13.164^{*}\left(<0.001^{*}\right)$} & \multicolumn{4}{|c|}{$23.298^{*}\left(<0.001^{*}\right)$} \\
\hline
\end{tabular}


Table (4): Number and percent distribution of the control group according to their pain intensity before and after the intervention at different periods first month $(n=50)$

\begin{tabular}{|c|c|c|c|c|c|c|c|c|c|c|c|c|}
\hline \multirow{4}{*}{$\begin{array}{l}\text { Menstrual pain } \\
\text { intensity }\end{array}$} & \multicolumn{12}{|c|}{ Control $(\mathbf{n}=\mathbf{5 0})$} \\
\hline & \multicolumn{4}{|c|}{ First day } & \multicolumn{4}{|c|}{ Third day } & \multicolumn{4}{|c|}{ Fifth day } \\
\hline & \multicolumn{2}{|c|}{ Pre } & \multicolumn{2}{|c|}{ Post } & \multicolumn{2}{|c|}{ Pre } & \multicolumn{2}{|c|}{ Post } & \multicolumn{2}{|c|}{ Pre } & \multicolumn{2}{|c|}{ Post } \\
\hline & No. & $\%$ & No. & $\%$ & No. & $\%$ & No. & $\%$ & No. & $\%$ & No. & $\%$ \\
\hline No pain & 0 & 0.0 & 0 & 0.0 & 0 & 0.0 & 0 & 0.0 & 0 & 0.0 & 4 & 8.0 \\
\hline Mild pain & 0 & 0.0 & 0 & 0.0 & 0 & 0.0 & 0 & 0.0 & 0 & 0.0 & 30 & 60.0 \\
\hline Moderate pain & 0 & 0.0 & 7 & 14.0 & 0 & 0.0 & 29 & 58.0 & 22 & 44.0 & 16 & 32.0 \\
\hline Severe pain & 23 & 46.0 & 28 & 56.0 & 37 & 74.0 & 21 & 42.0 & 26 & 52.0 & 0 & 0.0 \\
\hline Worst pain & 27 & 54.0 & 15 & 30.0 & 13 & 26.0 & 0 & 0.0 & 2 & 4.0 & 0 & 0.0 \\
\hline MH (p) & \multicolumn{4}{|c|}{$98.50^{*}\left(<0.001^{*}\right)$} & \multicolumn{4}{|c|}{$144.0^{*}\left(<0.001^{*}\right)$} & \multicolumn{4}{|c|}{$9.50^{*}\left(<0.001^{*}\right)$} \\
\hline Mean \pm SD. & \multicolumn{2}{|c|}{$9.22 \pm 0.91$} & \multicolumn{2}{|c|}{$8.26 \pm 1.43$} & \multicolumn{2}{|c|}{$8.84 \pm 0.82$} & \multicolumn{2}{|c|}{$6.08 \pm 1.64$} & 6.36 & 1.40 & \multicolumn{2}{|c|}{$2.48 \pm 1.45$} \\
\hline$t(p)$ & \multicolumn{4}{|c|}{$4.201^{*}\left(<0.001^{*}\right)$} & \multicolumn{4}{|c|}{$14.157^{*}\left(<0.001^{*}\right)$} & \multicolumn{4}{|c|}{$18.371^{*}\left(<0.001^{*}\right)$} \\
\hline
\end{tabular}

Significant $p$ at $\leq 0.05$

Table (5): Number and percent distribution of study and control groups according to their menstrual pain intensity before and after the intervention

\begin{tabular}{|c|c|c|c|c|c|c|c|c|c|c|c|c|}
\hline \multirow{4}{*}{$\begin{array}{l}\text { Menstrual } \\
\text { pain intensity }\end{array}$} & \multicolumn{4}{|c|}{ First day } & \multicolumn{4}{|c|}{ Third day } & \multicolumn{4}{|c|}{ Fifth day } \\
\hline & \multicolumn{2}{|c|}{ Pre } & \multicolumn{2}{|c|}{ Post } & \multicolumn{2}{|c|}{ Pre } & \multicolumn{2}{|c|}{ Post } & \multicolumn{2}{|c|}{ Pre } & \multicolumn{2}{|c|}{ Post } \\
\hline & $\begin{array}{c}\text { Study } \\
(n=50)\end{array}$ & $\begin{array}{l}\text { Control } \\
(\mathbf{n}=\mathbf{5 0})\end{array}$ & $\begin{array}{c}\text { Study } \\
(\mathbf{n}=\mathbf{5 0})\end{array}$ & $\begin{array}{l}\text { Control } \\
(\mathrm{n}=\mathbf{5 0})\end{array}$ & $\begin{array}{c}\text { Study } \\
(\mathbf{n}=\mathbf{5 0})\end{array}$ & $\begin{array}{l}\text { Control } \\
(\mathbf{n}=\mathbf{5 0})\end{array}$ & $\begin{array}{c}\text { Study } \\
(\mathbf{n}=\mathbf{5 0})\end{array}$ & $\begin{array}{l}\text { Control } \\
(\mathbf{n}=\mathbf{5 0})\end{array}$ & $\begin{array}{c}\text { Study } \\
(\mathbf{n}=\mathbf{5 0})\end{array}$ & $\begin{array}{l}\text { Control } \\
(\mathbf{n}=\mathbf{5 0})\end{array}$ & $\begin{array}{c}\text { Study } \\
(\mathbf{n}=\mathbf{5 0})\end{array}$ & $\begin{array}{l}\text { Control } \\
(\mathbf{n}=\mathbf{5 0})\end{array}$ \\
\hline & $\%$ & $\%$ & $\%$ & $\%$ & $\%$ & $\%$ & $\%$ & $\%$ & $\%$ & $\%$ & $\%$ & $\%$ \\
\hline No pain & 0.0 & 0.0 & 0.0 & 0.0 & 0.0 & 0.0 & 0.0 & 0.0 & 0.0 & 0.0 & 14.0 & 8.0 \\
\hline Mild pain & 0.0 & 0.0 & 0.0 & 0.0 & 0.0 & 0.0 & 14.0 & 0.0 & 14.0 & 0.0 & 74.0 & 60.0 \\
\hline Moderate pain & 0.0 & 0.0 & 30.0 & 14.0 & 0.0 & 0.0 & 60.0 & 58.0 & 60.0 & 58.0 & 12.0 & 32.0 \\
\hline Severe pain & 40.0 & 46.0 & 64.0 & 56.0 & 74.0 & 74.0 & 26.0 & 42.0 & 26.0 & 42.0 & 0.0 & 0.0 \\
\hline Worst pain & 60.0 & 54.0 & 6.0 & 30.0 & 26.0 & 26.0 & 0.0 & 0.0 & 0.0 & 0.0 & 0.0 & 0.0 \\
\hline$\chi^{2}(\mathbf{p})$ & \multicolumn{2}{|c|}{$0.367(0.545)$} & \multicolumn{2}{|c|}{$\begin{array}{l}11.176^{*} \\
\left(0.004^{*}\right)\end{array}$} & \multicolumn{2}{|c|}{$0.0(1.000)$} & \multicolumn{2}{|c|}{$\begin{array}{c}9.186^{*} \\
\left({ }^{\mathrm{MC}} \mathrm{p}=0.009^{*}\right)\end{array}$} & \multicolumn{2}{|c|}{$\begin{array}{c}3.744 \\
\left({ }^{\mathrm{MC}} \mathrm{p}=0.297\right) \\
\end{array}$} & \multicolumn{2}{|c|}{$6.095^{*}\left(0.047^{*}\right)$} \\
\hline Mean \pm SD & $\begin{array}{c}9.32 \pm \\
0.89\end{array}$ & $\begin{array}{c}9.22 \pm \\
0.91\end{array}$ & $\begin{array}{l}7.0 \pm \\
1.44\end{array}$ & $\begin{array}{c}8.26 \\
\pm 1.43\end{array}$ & $\begin{array}{c}8.62 \pm \\
1.19\end{array}$ & $\begin{array}{c}8.84 \pm \\
0.82\end{array}$ & $\begin{array}{c}5.40 \pm \\
1.76\end{array}$ & $\begin{array}{c}6.08 \pm \\
1.64\end{array}$ & $\begin{array}{c}6.34 \pm \\
1.71\end{array}$ & $\begin{array}{c}6.36 \pm \\
1.40\end{array}$ & $\begin{array}{l}1.92 \pm \\
1.35\end{array}$ & $\begin{array}{c}2.48 \pm \\
1.45\end{array}$ \\
\hline $\mathbf{t}(\mathbf{p})$ & \multicolumn{2}{|c|}{$0.555(0.580)$} & \multicolumn{2}{|c|}{$\begin{array}{c}4.392^{*} \\
\left(<0.001^{*}\right)\end{array}$} & \multicolumn{2}{|c|}{$1.076(0.285)$} & \multicolumn{2}{|c|}{$1.998^{*}\left(0.048^{*}\right)$} & \multicolumn{2}{|c|}{$0.064(0.949)$} & \multicolumn{2}{|c|}{$2.000^{*}\left(0.048^{*}\right)$} \\
\hline
\end{tabular}


Table (6a): Number and percent distribution of the study group according to their physical symptoms at different periods before and after intervention $(n=50)$

\begin{tabular}{|c|c|c|c|c|c|c|c|}
\hline & & \multicolumn{6}{|c|}{ Study $(n=50)$} \\
\hline \multirow{2}{*}{\multicolumn{2}{|c|}{ Physical symptoms }} & \multicolumn{2}{|c|}{ First day } & \multicolumn{2}{|c|}{ Third day } & \multicolumn{2}{|c|}{ Fifth day } \\
\hline & & Pre & Post & Pre & Post & Pre & Post \\
\hline & & No. & No. & No. & No. & No. & No. \\
\hline \multirow{5}{*}{ 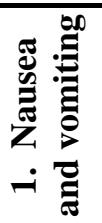 } & Absent & 0 & 0.0 & 0.0 & 6 & 6 & 16 \\
\hline & Mild & 0 & 11 & 6 & 22 & 11 & 30 \\
\hline & Moderate & 7 & 36 & 28 & 22 & 33 & 4 \\
\hline & Severe & 43 & 3 & 16 & 0 & 0.0 & 0.0 \\
\hline & MH (p) & \multicolumn{2}{|c|}{$106.50^{*}\left(<0.001^{*}\right)$} & \multicolumn{2}{|c|}{$76.00^{*}\left(<0.001^{*}\right)$} & \multicolumn{2}{|c|}{$45.50^{*}\left(<0.001^{*}\right)$} \\
\hline \multirow{5}{*}{ 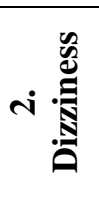 } & Absent & 7 & 34 & 27 & 30 & 26 & 47 \\
\hline & Mild & 10 & 5 & 3 & 10 & 12 & 3 \\
\hline & Moderate & 26 & 11 & 14 & 10 & 12 & 0 \\
\hline & Severe & 7 & 0 & 6 & 0 & 0 & 0 \\
\hline & MH (p) & \multicolumn{2}{|c|}{$47.00^{*}\left(<0.001^{*}\right)$} & \multicolumn{2}{|c|}{$25.50^{*}\left(<0.001^{*}\right)$} & \multicolumn{2}{|c|}{$19.50^{*}\left(<0.001^{*}\right)$} \\
\hline \multirow{5}{*}{ 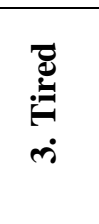 } & Absent & 11 & 34 & 20 & 37 & 37 & 44 \\
\hline & Mild & 23 & 3 & 17 & 10 & 4 & 6 \\
\hline & Moderate & 3 & 7 & 13 & 3 & 9 & 0 \\
\hline & Severe & 13 & 6 & 0 & 0 & 0 & 0 \\
\hline & MH (p) & \multicolumn{2}{|c|}{$33.50^{*}\left(<0.001^{*}\right)$} & \multicolumn{2}{|c|}{$23.50^{*}\left(<0.001^{*}\right)$} & \multicolumn{2}{|c|}{$14.00^{*}\left(0.001^{*}\right)$} \\
\hline \multirow{5}{*}{ 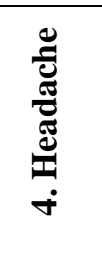 } & Absent & 15 & 27 & 27 & 27 & 27 & 40 \\
\hline & Mild & 0 & 3 & 3 & 16 & 13 & 10 \\
\hline & Moderate & 18 & 13 & 17 & 7 & 10 & 0 \\
\hline & Severe & 17 & 7 & 3 & 0 & 0 & 0 \\
\hline & MH (p) & \multicolumn{2}{|c|}{$41.50^{*}\left(<0.001^{*}\right)$} & \multicolumn{2}{|c|}{$24.00^{*}\left(0.002^{*}\right)$} & \multicolumn{2}{|c|}{$21.50^{*}\left(<0.001^{*}\right)$} \\
\hline
\end{tabular}

Significant $p$ at $\leq 0.05$

Table (6b): Number and percent distribution of the study group according to their psychological symptoms at different periods before and after intervention $(n=50)$

\begin{tabular}{|c|c|c|c|c|c|c|c|}
\hline \multirow{3}{*}{\multicolumn{2}{|c|}{ Psychological symptoms }} & \multicolumn{6}{|c|}{ Study $(\mathrm{n}=\mathbf{5 0})$} \\
\hline & & \multicolumn{2}{|c|}{ First day } & \multicolumn{2}{|c|}{ Third day } & \multicolumn{2}{|c|}{ Fifth day } \\
\hline & & \multirow{2}{*}{$\begin{array}{l}\text { Pre } \\
\text { No. }\end{array}$} & \multirow{2}{*}{$\begin{array}{l}\text { Post } \\
\text { No. }\end{array}$} & \multirow{2}{*}{$\begin{array}{l}\text { Pre } \\
\text { No. }\end{array}$} & \multirow{2}{*}{$\begin{array}{l}\text { Post } \\
\text { No. }\end{array}$} & \multirow{2}{*}{$\begin{array}{l}\text { Pre } \\
\text { No. }\end{array}$} & \multirow{2}{*}{$\begin{array}{l}\text { Post } \\
\text { No. }\end{array}$} \\
\hline & & & & & & & \\
\hline ๘ี & Absent & 30 & 30 & 30 & 36 & 36 & 42 \\
\hline 娄 & Mild & 0 & 0 & 3 & 3 & 6 & 8 \\
\hline 茪 & Moderate & 3 & 12 & 7 & 11 & 8 & 0 \\
\hline ڤั̀ & Severe & 17 & 8 & 10 & 0 & 0 & 0 \\
\hline$\dot{10}$ & MH (p) & \multicolumn{2}{|c|}{$22.50^{*}\left(0.003^{*}\right)$} & \multicolumn{2}{|c|}{$28.00^{*}\left(0.001^{*}\right)$} & \multicolumn{2}{|c|}{$15.00^{*}\left(<0.001^{*}\right)$} \\
\hline \multirow{5}{*}{ 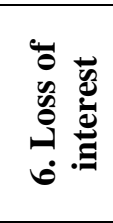 } & Absent & 41 & 41 & 39 & 43 & 42 & 47 \\
\hline & Mild & 0 & 0 & 3 & 3 & 3 & 3 \\
\hline & Moderate & 0 & 7 & 8 & 4 & 5 & 0 \\
\hline & Severe & 9 & 2 & 0 & 0 & 0 & 0 \\
\hline & MH (p) & \multicolumn{2}{|c|}{$17.50^{*}\left(0.008^{*}\right)$} & \multicolumn{2}{|c|}{$7.00^{*}\left(0.0033^{*}\right)$} & \multicolumn{2}{|c|}{$8.00^{*}\left(0.008^{*}\right)$} \\
\hline \multirow{5}{*}{ 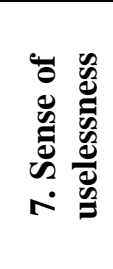 } & Absent & 37 & 37 & 37 & 40 & 40 & 43 \\
\hline & Mild & 0 & 0 & 0 & 6 & 2 & 7 \\
\hline & Moderate & 3 & 6 & 6 & 4 & 5 & 0 \\
\hline & Severe & 10 & 7 & 7 & 0 & 3 & 0 \\
\hline & MH (p) & \multicolumn{2}{|c|}{$7.50(0.083)$} & \multicolumn{2}{|c|}{$15.50^{*}\left(0.005^{*}\right)$} & \multicolumn{2}{|c|}{$12.00^{*}\left(0.008^{*}\right)$} \\
\hline
\end{tabular}


Table (7a): Number and percent distribution of control group according to their physical symptoms at different periods before and after intervention $(n=50)$

\begin{tabular}{|c|c|c|c|c|c|c|c|}
\hline \multirow{3}{*}{\multicolumn{2}{|c|}{ Physical symptoms }} & \multicolumn{6}{|c|}{ Control $(n=50)$} \\
\hline & & \multicolumn{2}{|c|}{ First day } & \multicolumn{2}{|c|}{ Third day } & \multicolumn{2}{|c|}{ Fifth day } \\
\hline & & \multirow{2}{*}{$\begin{array}{l}\text { Pre } \\
\text { No. }\end{array}$} & \multirow{2}{*}{$\begin{array}{l}\text { Post } \\
\text { No. }\end{array}$} & \multirow{2}{*}{$\begin{array}{l}\text { Pre } \\
\text { No. }\end{array}$} & \multirow{2}{*}{$\begin{array}{l}\text { Post } \\
\text { No. }\end{array}$} & \multirow{2}{*}{$\begin{array}{l}\text { Pre } \\
\text { No. }\end{array}$} & \multirow{2}{*}{$\begin{array}{c}\text { Post } \\
\text { No. }\end{array}$} \\
\hline & & & & & & & \\
\hline \multirow{5}{*}{ 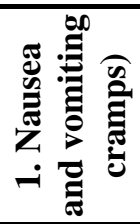 } & Absent & 0 & 0 & 0 & 0 & 7 & 22 \\
\hline & Mild & 0 & 4 & 4 & 7 & 15 & 13 \\
\hline & Moderate & 4 & 37 & 27 & 29 & 28 & 15 \\
\hline & Severe & 46 & 9 & 19 & 14 & 0.0 & 0.0 \\
\hline & MH (p) & \multicolumn{2}{|c|}{$98.50^{*}\left(<0.001^{*}\right)$} & \multicolumn{2}{|c|}{$15.00^{*}\left(0.011^{*}\right)$} & \multicolumn{2}{|c|}{$27.00^{*}\left(<0.001^{*}\right)$} \\
\hline \multirow{5}{*}{ 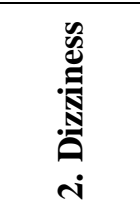 } & Absent & 9 & 9 & 22 & 25 & 22 & 21 \\
\hline & Mild & 3 & 3 & 3 & 5 & 17 & 20 \\
\hline & Moderate & 29 & 33 & 19 & 15 & 11 & 9 \\
\hline & Severe & 9 & 5 & 6 & 5 & 0 & 0 \\
\hline & MH (p) & \multicolumn{2}{|c|}{$10.00^{*}\left(0.046^{*}\right)$} & \multicolumn{2}{|c|}{$9.500^{*}\left(0.007^{*}\right)$} & \multicolumn{2}{|c|}{$5.500(0.705)$} \\
\hline \multirow{5}{*}{ 它 } & Absent & 8 & 16 & 23 & 23 & 33 & 43 \\
\hline & Mild & 16 & 6 & 10 & 10 & 10 & 7 \\
\hline & Moderate & 9 & 13 & 14 & 14 & 7 & 0 \\
\hline & Severe & 17 & 15 & 3 & 3 & 0 & 0 \\
\hline & MH (p) & \multicolumn{2}{|c|}{$15.00(0.117)$} & \multicolumn{2}{|c|}{$0.0(1.00)$} & \multicolumn{2}{|c|}{$11.50 *\left(<0.001^{*}\right)$} \\
\hline \multirow{5}{*}{ 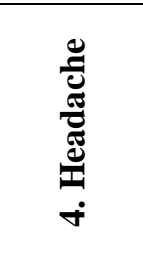 } & Absent & 23 & 22 & 23 & 23 & 33 & 47 \\
\hline & Mild & 3 & 4 & 7 & 27 & 14 & 3 \\
\hline & Moderate & 10 & 13 & 14 & 0 & 3 & 0 \\
\hline & Severe & 14 & 11 & 6 & 0 & 0 & 0 \\
\hline & MH (p) & \multicolumn{2}{|c|}{$22.0(0.655)$} & \multicolumn{2}{|c|}{$33.00^{*}\left(<0.001^{*}\right)$} & \multicolumn{2}{|c|}{$11.50^{*}\left(<0.001^{*}\right)$} \\
\hline
\end{tabular}

Significant $p$ at $\leq 0.05$

Table (7b): Number and percent distribution of the control group according to their psychological symptoms at different periods before and after intervention $(n=50)$

\begin{tabular}{|c|c|c|c|c|c|c|c|}
\hline \multirow{3}{*}{\multicolumn{2}{|c|}{ psychological symptoms }} & \multicolumn{6}{|c|}{ Control $(n=50)$} \\
\hline & & \multicolumn{2}{|c|}{ First day } & \multicolumn{2}{|c|}{ Third day } & \multicolumn{2}{|c|}{ Fifth day } \\
\hline & & \multirow{2}{*}{$\begin{array}{l}\text { Pre } \\
\text { No. } \\
\end{array}$} & \multirow{2}{*}{\begin{tabular}{|l} 
Post \\
No. \\
\end{tabular}} & \multirow{2}{*}{\begin{tabular}{|l|} 
Pre \\
No.
\end{tabular}} & \multirow{2}{*}{\begin{tabular}{|c|} 
Post \\
No. \\
\end{tabular}} & \multirow{2}{*}{$\begin{array}{l}\text { Pre } \\
\text { No. } \\
\end{array}$} & \multirow{2}{*}{\begin{tabular}{|l|} 
Post \\
No. \\
\end{tabular}} \\
\hline & & & & & & & \\
\hline \multirow{5}{*}{ 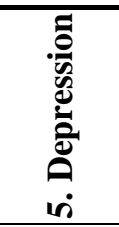 } & Absent & 29 & 36 & 36 & 50 & 41 & 46 \\
\hline & Mild & 0 & 0 & 0 & 0 & 2 & 4 \\
\hline & Moderate & 2 & 2 & 4 & 0 & 7 & 0 \\
\hline & Severe & 19 & 12 & 10 & 0 & 0 & 0 \\
\hline & MH (p) & \multicolumn{2}{|c|}{$12.50^{*}\left(0.006^{*}\right)$} & \multicolumn{2}{|c|}{$3.448^{*}\left(0.001^{*}\right)$} & \multicolumn{2}{|c|}{$10.00^{*}\left(0.005^{*}\right)$} \\
\hline \multirow{5}{*}{ 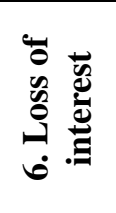 } & Absent & 38 & 38 & 38 & 38 & 38 & 38 \\
\hline & Mild & 0 & 0 & 0 & 2 & 0 & 12 \\
\hline & Moderate & 0 & 2 & 11 & 10 & 11 & 0 \\
\hline & Severe & 12 & 10 & 1 & 0 & 1 & 0 \\
\hline & MH (p) & \multicolumn{2}{|c|}{$5.00(0.157)$} & \multicolumn{2}{|c|}{$3.500(0.180)$} & \multicolumn{2}{|c|}{$18.50^{*}\left(0.001^{*}\right)$} \\
\hline \multirow{5}{*}{ 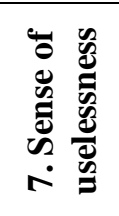 } & Absent & 37 & 37 & 37 & 37 & 37 & 40 \\
\hline & Mild & 0 & 0 & 0 & 3 & 3 & 5 \\
\hline & Moderate & 1 & 7 & 9 & 9 & 6 & 4 \\
\hline & Severe & 12 & 6 & 4 & 1 & 4 & 1 \\
\hline & MH (p) & \multicolumn{2}{|c|}{$15.00^{*}\left(0.014^{*}\right)$} & \multicolumn{2}{|c|}{$12.00^{*}\left(0.014^{*}\right)$} & \multicolumn{2}{|c|}{$16.500^{*}\left(0.001^{*}\right)$} \\
\hline
\end{tabular}


Table (8a): Number and percent distribution of the study and control groups according to their physical symptoms at different periods before and after intervention $(n=50)$

\begin{tabular}{|c|c|c|c|c|c|c|c|c|c|c|c|c|}
\hline \multirow{4}{*}{$\begin{array}{c}\text { Physical } \\
\text { symptoms }\end{array}$} & \multicolumn{4}{|c|}{ First day } & \multicolumn{4}{|c|}{ Third day } & \multicolumn{4}{|c|}{ Fifth day } \\
\hline & \multicolumn{2}{|c|}{ Pre } & \multicolumn{2}{|c|}{ Post } & \multicolumn{2}{|c|}{ Pre } & \multicolumn{2}{|c|}{ Post } & \multicolumn{2}{|c|}{ Pre } & \multicolumn{2}{|c|}{ Post } \\
\hline & $\begin{array}{c}\text { Study } \\
(\mathrm{n}=50)\end{array}$ & $\begin{array}{c}\text { Control } \\
(\mathbf{n}=50)\end{array}$ & $\begin{array}{c}\text { Study } \\
(\mathrm{n}=50)\end{array}$ & $\begin{array}{l}\text { Control } \\
(\mathbf{n}=\mathbf{5 0})\end{array}$ & $\begin{array}{c}\text { Study } \\
(\mathbf{n = 5 0})\end{array}$ & $\begin{array}{l}\text { Control } \\
(\mathrm{n}=50)\end{array}$ & \begin{tabular}{|c|} 
Study \\
$(\mathbf{n}=\mathbf{5 0})$
\end{tabular} & $\begin{array}{c}\text { Control } \\
(\mathrm{n}=50)\end{array}$ & $\begin{array}{c}\text { Study } \\
(\mathbf{n}=\mathbf{5 0})\end{array}$ & $\begin{array}{l}\text { Control } \\
(\mathbf{n}=50)\end{array}$ & $\begin{array}{c}\begin{array}{c}\text { Study } \\
(\mathbf{n}=50)\end{array} \\
\end{array}$ & $\begin{array}{l}\text { Control } \\
(\mathbf{n}=\mathbf{5 0})\end{array}$ \\
\hline & $\%$ & $\%$ & $\%$ & $\%$ & $\%$ & $\%$ & $\%$ & $\%$ & $\%$ & $\%$ & $\%$ & $\%$ \\
\hline \multirow{4}{*}{ 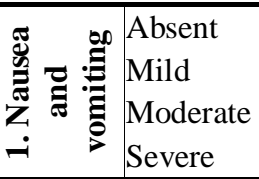 } & 0.0 & 0.0 & 0.0 & 0.0 & 0.0 & 0.0 & 12.0 & 0.0 & 12.0 & 14.0 & 32.0 & 44.0 \\
\hline & 0 & 0.0 & 2.0 & & 12.0 & 8 & 44.0 & & 2.0 & 30.0 & 60.0 & \\
\hline & 14.0 & 8.0 & 72.0 & 74.0 & 56.0 & 54.0 & 44.0 & & 66.0 & 56.0 & 8.0 & 30.0 \\
\hline & 86.0 & 92.0 & 6.0 & 18.0 & 32.0 & 38.0 & 0.0 & 28.0 & 0.0 & 0.0 & 0.0 & 0.0 \\
\hline$\chi^{2}(\mathrm{p})$ & \multicolumn{2}{|c|}{$\begin{array}{c}0.919 \\
(0.338)\end{array}$} & \multicolumn{2}{|c|}{$\begin{array}{c}6.280^{*} \\
\left(0.043^{*}\right)\end{array}$} & \multicolumn{2}{|c|}{$\begin{array}{c}0.675 \\
(0.713)\end{array}$} & \multicolumn{2}{|c|}{$\begin{array}{c}31.204^{*} \\
\left({ }^{\mathrm{MC}}<<0.001^{*}\right)\end{array}$} & \multicolumn{2}{|c|}{$\begin{array}{c}1.102 \\
(0.576)\end{array}$} & \multicolumn{2}{|c|}{$\begin{array}{l}14.037^{*} \\
\left(0.001^{*}\right)\end{array}$} \\
\hline \multirow{4}{*}{ 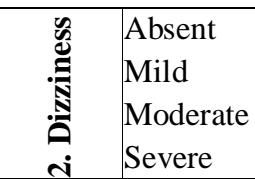 } & 14.0 & 18.0 & 68.0 & 18.0 & 54.0 & 44.0 & 60.0 & 50.0 & 52.0 & 44.0 & 94.0 & 42.0 \\
\hline & 20.0 & 6.0 & 10.0 & 6.0 & 6.0 & 6.0 & 20.0 & & 24.0 & 34.0 & 6.0 & 40.0 \\
\hline & 52.0 & 58.0 & 22.0 & 66.0 & 28.0 & 38.0 & 20.0 & & 24.0 & 22.0 & 0.0 & 18.0 \\
\hline & 14.0 & 18.0 & 0.0 & 10.0 & 12.0 & 12.0 & 0.0 & 10.0 & 0.0 & 0.0 & 0.0 & 0.0 \\
\hline$\chi^{2}(\mathrm{p})$ & \multicolumn{2}{|c|}{$\begin{array}{c}4.433 \\
(0.218) \\
\end{array}$} & \multicolumn{2}{|c|}{$\begin{array}{c}31.035^{*} \\
\left({ }^{\mathrm{MC}}<00.001^{*}\right)\end{array}$} & \multicolumn{2}{|c|}{$\begin{array}{c}1.383 \\
\left({ }^{\mathrm{MC}}=0.734\right)\end{array}$} & \multicolumn{2}{|c|}{$\begin{array}{c}7.929^{*} \\
\left({ }^{\mathrm{MC}} \mathrm{p}=0.040^{*}\right)\end{array}$} & \multicolumn{2}{|c|}{$\begin{array}{c}1.239 \\
(0.538) \\
\end{array}$} & \multicolumn{2}{|c|}{$\begin{array}{c}33.212^{*} \\
\left({ }^{\mathrm{MC}}<00.001^{*}\right)\end{array}$} \\
\hline & 22.0 & 16.0 & 68.0 & 32.0 & 40.0 & 46.0 & 74.0 & 46.0 & 74.0 & 66.0 & 88.0 & 86.0 \\
\hline & 46.0 & 32.0 & 6.0 & & 34.0 & 20.0 & 20.0 & & 8.0 & 20.0 & 12.0 & 14.0 \\
\hline & 6.0 & 18.0 & 14.0 & & 26.0 & 28.0 & 6.0 & 28 & 18.0 & 14.0 & 0.0 & 0.0 \\
\hline & 26.0 & 34.0 & 12.0 & 30.0 & 0.0 & 6.0 & 0.0 & 6.0 & 0.0 & 0.0 & 0.0 & 0.0 \\
\hline$\chi^{2}(\mathrm{p})$ & \multicolumn{2}{|c|}{$\begin{array}{c}5.263 \\
(0.153)\end{array}$} & \multicolumn{2}{|c|}{$\begin{array}{c}13.037^{*} \\
\left({ }^{\mathrm{MC}} \mathrm{p}=0.004^{*}\right)\end{array}$} & \multicolumn{2}{|c|}{$\begin{array}{c}4.661 \\
\left({ }^{\mathrm{MC}} \mathrm{p}=0.183\right)\end{array}$} & $\begin{array}{r}13.1 \\
\mathrm{MC}_{\mathrm{p}}=0\end{array}$ & $\begin{array}{l}117^{*} \\
\left.0.003^{*}\right)\end{array}$ & $\begin{array}{r}3.0 \\
(0.2\end{array}$ & & $\begin{array}{r}0.0 \\
(0.7\end{array}$ & \\
\hline Absent & 30.0 & 46.0 & 54.0 & 44.0 & 54.0 & 46.0 & 54.0 & 46.0 & 54.0 & 66.0 & 80.0 & 94.0 \\
\hline Mild & 0.0 & 6.0 & 6.0 & 8.0 & 6.0 & 14.0 & 32.0 & 54.0 & 26.0 & 28.0 & 20.0 & 6.0 \\
\hline 苛 Moder & 36.0 & 20.0 & 26.0 & 26.0 & 34.0 & 28.0 & 14.0 & 0.0 & 20.0 & 6.0 & 0.0 & 0.0 \\
\hline i & 34.0 & 28.0 & 14.0 & 22.0 & 6.0 & 12.0 & 0.0 & 0.0 & 0.0 & 0.0 & 0.0 & 0.0 \\
\hline$\chi^{2}(\mathbf{p})$ & $\begin{array}{r}6.8 \\
\left({ }^{\mathrm{MC}}=\right.\end{array}$ & $\begin{array}{l}320 \\
0.062)\end{array}$ & $\left({ }^{\mathrm{MC}} 1\right.$. & $\begin{array}{l}596 \\
0.687)\end{array}$ & $\begin{array}{r}3.1 \\
{ }^{\mathrm{MC}} \mathrm{p}=\end{array}$ & $\begin{array}{l}117 \\
=0.37)\end{array}$ & $\begin{array}{r}10.4 \\
\left({ }^{\mathrm{MC}} \mathrm{p}=0\right.\end{array}$ & $\begin{array}{l}416 \\
\left.0.005^{*}\right)\end{array}$ & & $\begin{array}{l}406 \\
110)\end{array}$ & $\begin{array}{r}4.3 \\
(0.0\end{array}$ & $\begin{array}{l}32^{*} \\
\left.37^{*}\right)\end{array}$ \\
\hline
\end{tabular}


Table (8b): Number and percent distribution of the study and control groups according to their psychological symptoms at different periods before and after intervention $(n=50)$

\begin{tabular}{|c|c|c|c|c|c|c|c|c|c|c|c|c|c|}
\hline \multirow{3}{*}{\multicolumn{2}{|c|}{\begin{tabular}{|l} 
Psychological \\
symptoms
\end{tabular}}} & \multicolumn{4}{|c|}{ First day } & \multicolumn{4}{|c|}{ Third day } & \multicolumn{4}{|c|}{ Fifth day } \\
\hline & & \multicolumn{2}{|c|}{ Pre } & \multicolumn{2}{|c|}{ Post } & \multicolumn{2}{|c|}{\begin{tabular}{|c|} 
Pre \\
\end{tabular}} & \multicolumn{2}{|c|}{ Post } & \multicolumn{2}{|c|}{ Pre } & \multicolumn{2}{|c|}{ Post } \\
\hline & & $\begin{array}{l}\text { Study } \\
(\mathbf{n}=50)\end{array}$ & $\begin{array}{l}\text { Control } \\
(\mathrm{n}=50)\end{array}$ & $\begin{array}{c}\text { Study } \\
(\mathbf{n}=50)\end{array}$ & $\begin{array}{l}\text { Control } \\
(\mathbf{n}=\mathbf{5 0})\end{array}$ & $\begin{array}{c}\text { Study } \\
(\mathrm{n}=\mathbf{5 0})\end{array}$ & $\begin{array}{l}\text { Control } \\
(\mathbf{n}=\mathbf{5 0})\end{array}$ & \begin{tabular}{|c} 
Study \\
$(\mathrm{n}=\mathbf{5 0})$
\end{tabular} & $\begin{array}{l}\text { Control } \\
(\mathbf{n}=50)\end{array}$ & $\begin{array}{c}\text { Study } \\
(\mathrm{n}=50)\end{array}$ & $\begin{array}{c}\text { Control } \\
(\mathbf{n}=50)\end{array}$ & $\begin{array}{c}\text { Study } \\
(\mathrm{n}=50)\end{array}$ & $\begin{array}{l}\text { Control } \\
(\mathbf{n}=\mathbf{5 0})\end{array}$ \\
\hline \multirow{5}{*}{ 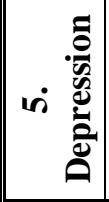 } & & & & & & & & & & & & & \\
\hline & Absent & 60.0 & 58.0 & 60.0 & 72.0 & 60.0 & 72.0 & 72.0 & 100.0 & 72.0 & 82.0 & 84.0 & 92.0 \\
\hline & Mild & 0.0 & 0.0 & 0.0 & 0.0 & 6.0 & 0.0 & 6.0 & 0.0 & 12.0 & 4.0 & 16.0 & 8.0 \\
\hline & Moderate & 6.0 & 4.0 & 24.0 & 4.0 & 14.0 & 8.0 & 22.0 & 0.0 & 16.0 & 14.0 & 0.0 & 0.0 \\
\hline & Severe & 34.0 & 38.0 & 16.0 & 24.0 & 20.0 & 20.0 & 0.0 & 0.0 & 0.0 & 0.0 & 0.0 & 0.0 \\
\hline \multicolumn{2}{|c|}{$\chi^{2}(\mathbf{p})$} & \multicolumn{2}{|c|}{$\begin{array}{c}0.407 \\
\left({ }^{\mathrm{MC}} \mathrm{p}=0.894\right)\end{array}$} & \multicolumn{2}{|c|}{$\begin{array}{c}8.488^{*} \\
\left(0.014^{*}\right)\end{array}$} & \multicolumn{2}{|c|}{$\begin{array}{c}3.976 \\
\left({ }^{\mathrm{MC}} \mathrm{p}=0.248\right)\end{array}$} & \multicolumn{2}{|c|}{$\begin{array}{c}17.272^{*} \\
\left({ }^{\mathrm{MC}} \mathrm{p}<0.001^{*}\right)\end{array}$} & \multicolumn{2}{|c|}{$\begin{array}{c}2.313 \\
\left({ }^{\mathrm{MC}} \mathrm{p}=0.321\right)\end{array}$} & \multicolumn{2}{|c|}{$\begin{array}{l}1.515 \\
(0.218)\end{array}$} \\
\hline \multirow{4}{*}{ 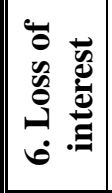 } & Absent & 82.0 & 76.0 & 82.0 & 76.0 & 78.0 & 76.0 & 86.0 & 76.0 & 84.0 & 76.0 & 94.0 & 76.0 \\
\hline & Mild & 0.0 & 0.0 & 0.0 & 0.0 & 6.0 & 0.0 & 6.0 & 4.0 & 6.0 & 0.0 & 6.0 & 24.0 \\
\hline & Moderate & 0.0 & 0.0 & 14.0 & 4.0 & 16.0 & 22.0 & 8.0 & 20.0 & 10.0 & 22.0 & 0.0 & 0.0 \\
\hline & Severe & 18.0 & 24.0 & 4.0 & 20.0 & 0.0 & 2.0 & 0.0 & 0.0 & 0.0 & 2.0 & 0.0 & 0.0 \\
\hline \multicolumn{2}{|c|}{$\chi^{2}(\mathbf{p})$} & \multicolumn{2}{|c|}{$\begin{array}{c}0.542 \\
(0.461)\end{array}$} & \multicolumn{2}{|c|}{$\begin{array}{c}8.094^{*} \\
\left({ }^{\mathrm{MC}} \mathrm{p}=0.015^{*}\right)\end{array}$} & \multicolumn{2}{|c|}{$\begin{array}{c}4.035 \\
\left({ }^{\mathrm{MC}}=0.240\right)\end{array}$} & \multicolumn{2}{|c|}{$\left(\begin{array}{c}3.071 \\
\left({ }^{\mathrm{MC}}=0.229\right)\end{array}\right.$} & \multicolumn{2}{|c|}{$\begin{array}{c}5.935 \\
\left({ }^{\mathrm{MC}}=0.066\right)\end{array}$} & \multicolumn{2}{|c|}{$\begin{array}{c}6.353^{*} \\
\left(0.012^{*}\right)\end{array}$} \\
\hline \multirow{4}{*}{ 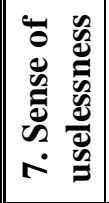 } & Absent & 74.0 & 74.0 & 74.0 & 74.0 & 74.0 & 74.0 & 80.0 & 74.0 & 80.0 & 74.0 & 86.0 & 80.0 \\
\hline & Mild & 0.0 & 0.0 & 0.0 & 0.0 & 0.0 & 0.0 & 12.0 & 6.0 & 4.0 & 6.0 & 14.0 & 10.0 \\
\hline & Moderate & 6.0 & 2.0 & 12.0 & 14.0 & 12.0 & 18.0 & 8.0 & 18.0 & 10.0 & 12.0 & 0.0 & 8.0 \\
\hline & Severe & 20.0 & 24.0 & 14.0 & 12.0 & 14.0 & 8.0 & 0.0 & 2.0 & 6.0 & 8.0 & 0.0 & 2.0 \\
\hline \multicolumn{2}{|c|}{$\chi^{2}(\mathbf{p})$} & \multicolumn{2}{|c|}{$\begin{array}{c}1.133 \\
\left({ }^{\mathrm{MC}} \mathrm{p}=0.611\right)\end{array}$} & \multicolumn{2}{|c|}{$\begin{array}{c}0.154 \\
(0.926)\end{array}$} & \multicolumn{2}{|c|}{$\begin{array}{c}1.418 \\
(0.492)\end{array}$} & \multicolumn{2}{|c|}{$\begin{array}{c}3.879 \\
\left({ }^{\mathrm{MC}} \mathrm{p}=0.235\right)\end{array}$} & \multicolumn{2}{|c|}{$\begin{array}{c}0.707 \\
\left({ }^{\mathrm{MC}} \mathrm{p}=0.871\right)\end{array}$} & $\left({ }^{\mathrm{MC}}{ }_{\mathrm{p}}^{5}\right.$ & $\begin{array}{l}100 \\
=0.120)\end{array}$ \\
\hline
\end{tabular}




\section{References}

- Alghadir, A.H., Al-Eisa, E.S., Anwer, S., Sarkar, B. (2018). Reliability, validity, and responsiveness of three scales for measuring balance in patients with chronic stroke. BMC Neurology, $18(1), 141$.

- Abdelmoty, H.I., Youssef, M.A., Abdallah, S., Abdel-Malak, K., Hashish, N.M., Samir, D, Seleem, M. (2015). Menstrual patterns and disorders among secondary school adolescents in Egypt. A cross-sectional survey. BMC Women's Health, 15, 70.

- American College of Obstetricians and Gynecologists [ACOG]. (2013). ACOG Committee opinion no. 548: weight gain during pregnancy. Obstetrics \& Gynecology, 121(1), 210-212.

- Arik M.I, Kiloatar,H, Aslan B, Icelli M.(2020). The effect of tens for pain relief in women with primary dysmenorrhea: A systematic review and meta-analysis. ELSEVER, 29, 2541.

- Bai, Hai-Yan MBa; Bai, Hong-Yan MBb; Yang, Zhi-Qin MB. (2017) Effect of transcutaneous electrical nerve stimulation therapy for the treatment of primary dysmenorrheal. $J$ of Medicine, 96 (36), 7959.

- Parsa P and Bashirian S (2013). Effect of Transcutaneous Electrical Nerve Stimulation (TENS) on primary dysmenorrhea in adolescent girls. $J$ of Postgraduate Medical Institute 27(3), 326-330.

- Davis AR, Westhoff C, O'Connell K, Gallagher N. (2005). Oral contraceptives for dysmenorrhea in adolescent girls: a randomized trial. Obstetrics and Gynecology, 106, 97104.

- Dawood MY, Ramos J (1990). Transcutaneous electrical nerve stimulation (TENS) for the treatment of primary dysmenorrhea: a randomized crossover comparison with placebo
TENS and ibuprofen. Obstet Gynecol, 75(4), 656-60.

- Elboim-Gabyzon M and Kalichman L (2020). Transcutaneous Electrical Nerve Stimulation (TENS) for Primary Dysmenorrhea: An Overview. International Journal of Women's Health, 8(12), 1-10.

- Hailemeskel, S., Demissie, A., \& Assefa, N. (2016). Primary dysmenorrhea magnitude, associated risk factors, and its effect on academic performance: evidence from female university students in Ethiopia. International Journal of Women's Health, 8, 489-496.

- Hai-Yan Bai, MB,a Hong-Yan Bai, MB,b and Zhi-Qin Yang, MB ( 2017) . Effect of transcutaneous electrical nerve stimulation therapy for the treatment of primary dysmenorrheal. $J$ of Medicine, 96(36), 7959.

- Herbst, A.L. (1996). Comprehensive gynecology (2nd ed.). Chicago, Mosby: Year Book Medical Publishers Inc.

- Iacovides, S., Avidon, I., \& Baker, F.C. (2015). What we know about primary dysmenorrhea today: a critical review. Human Reproduction Update, 21(6), 762-778.

- Jang, S.H., Kim, D.I., \& Choi, M.S. (2014). Effects and treatment methods of acupuncture and herbal medicine for premenstrual syndrome/premenstrual dysphoric disorder: systematic review. BMC Complementary and Alternative Medicine, 14, 11.

- $\quad$ Kang, S., Lee, Y. (2013). Menstruation and the Variability of food intake in female college students. Korean Journal of Community Nutrition, 18, 577.

- Katz, J., \& Melzack, R. (1999). Measurement of pain. Surgical Clinics of North America, 79(2), 231-252.

- Lauretti, G. R, Oliveira .R, Parada. R, Anita L Mattos, A. (2015). The New 
Portable Transcutaneous Electrical Nerve Stimulation Device Was Efficacious in the Control of Primary Dysmenorrhea Cramp Pain. $J$ of Neuromodulation 18(6):522-6.

- Marjoribanks, J., Proctor, M., Farquhar, C., \& Derks, R.S. (2010). Nonsteroidal anti-inflammatory drugs for dysmenorrhoea. The Cochrane Database of Systematic Reviews (1), Cd001751.

- Negriff, S., Dorn, L.D., Hillman, J.B., \& Huang, B. (2009). The measurement of menstrual symptoms: factor structure of the menstrual symptom questionnaire in adolescent girls. Journal of Health Psychology, 14(7), 899-908.

- Ojoawo OA, Esan O, \& Oloni DA. (2020). Effectiveness of Transcutaneous Electrical Nerve Stimulation on Pain and Disability Among Patients with Hip Arthroplasty: A Randomized Control Study of Rehabilitation and Health Studies 7(4), 3.

- Omidvar, S., \& Begum, K. (2012). Characteristics and determinants of primary dysmenorrhea in young adults. American Medical Journal, 3(1), 8-13.
- Ortiz, M.I. (2010). Primary dysmenorrhea among Mexican university students: prevalence, impact and treatment. European Journal of Obstetrics, Gynecology, and Reproductive Biology, 152(1), 73-77.

- Parsa, P., \& Bashirian, S. (2013). Effect of transcutaneous electrical nerve stimulation (TENS) on primary dysmenorrhea in adolescent girls. Journal of Postgraduate Medical Institute, 27 (3).

- Tomas-Rodriguez, M.I., Palazon-Bru, A., Martinez-St John, D.R., NavarroCremades, F., Toledo-Marhuenda, J.V., \& Gil-Guillen, V.F. (2017). Factors Associated with Increased Pain in Primary Dysmenorrhea: Analysis Using a Multivariate Ordered Logistic Regression Model. Journal of Pediatric and Adolescent Gynecology, 30(2), 199-202. 